\title{
Synthesis of whey peptide-iron complexes: Influence of using different iron precursor compounds
}

\author{
Maria Elisa Caetano-Silva ${ }^{\mathrm{a}}$, Renata Carolina Alves ${ }^{\mathrm{b}}$, Guilherme Nunes Lucena ${ }^{\mathrm{b}}$, \\ Regina Célia Galvão Frem ${ }^{\mathrm{b}, *}$, Maria Teresa Bertoldo-Pacheco ${ }^{\mathrm{c}}$, Juliana Azevedo Lima-Pallone ${ }^{\mathrm{a}}$, \\ Flavia Maria Netto ${ }^{\mathrm{a}, * *}$ \\ a Faculty of Food Engineering, University of Campinas, UNICAMP, Monteiro Lobato 80, 13083-862 Campinas, SP, Brazil \\ b Institute of Chemistry, São Paulo State University, UNESP, Prof. Francisco Degni 55, PO Box 355, 14800-970 Araraquara, SP, Brazil

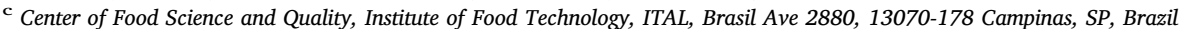

\section{A R T I C L E I N F O}

\section{Keywords:}

Iron-binding peptides

Coordination compounds

Infrared spectroscopy

Iron salts

Whey protein hydrolysate

Food fortification

\begin{abstract}
A B S T R A C T
Iron-binding peptides are an alternative for increasing the bioavailability of iron and to decreasing its prooxidant effect. This study aimed to synthesize and characterize peptide-iron complexes using $\mathrm{FeCl}_{2}$ or $\mathrm{FeSO}_{4}$ as the iron precursor compounds. Whey protein isolate (WPI), WPI hydrolyzed with pancreatin, and its fractions obtained via ultrafiltration (cut-off $5 \mathrm{kDa}$ ) were used as ligands. The fluorescence intensity of the ligands significantly decreased as the iron concentration increased as a result of metal coordination with the iron-binding sites, which may have led to changes in the microenvironment of tryptophan. For both iron precursor compounds, the primary iron-binding site was carboxylate groups, and the linkage occurred via a bidentate coordination mode with two vibrational modes assigned to the COO-Fe linkage. However, infrared spectroscopy and thermal analysis results showed that the dynamics of the interaction is different for the iron precursor. The iron source may be of great importance because it may impact iron absorption and the pro-oxidant effect of the mineral.
\end{abstract}

\section{Introduction}

Iron is an essential micronutrient and an intrinsic component of hemoglobin, myoglobin, and cytochromes (Luo \& Xie, 2012). This mineral acts as a regulator, activator, and controller of several enzymatic reactions. Among iron's functions, the formation of red blood cells, $\mathrm{O}_{2}$ and $\mathrm{CO}_{2}$ transport, electron transfer, redox reactions and cellular energy production can be highlighted (Lieu, Heiskala, Peterson, \& Yang, 2001). Therefore, iron deficiency is responsible for several diseases and is one of the primary nutritional problems worldwide. Many efforts have been made to combat this deficiency, mainly regarding food fortification. However, this practice is still a challenge due to the questions associated, such as low bioavailability, digestive problems, such as stomach ache or diarrhea, and even changes in the flavor and appearance of food products (Sugiarto, Ye, \& Singh, 2009).

Peptide-iron complexes can be an alternative to mitigate these problems. Under certain conditions, iron binding with an organic compound promotes the formation of complexes, which protects the micronutrient against the chemical reactions that occur during the digestive process (Gligic, Palic, \& Nikolovski, 2004). Iron-peptide binding is based on the interaction between an electron donator group at the ligand surface (in this case, peptide) and a Lewis acid (transition metal ion). Peptides may present one or more accessible coordinating sites, ensuring that the metal atom becomes part of a biologically stable structure through coordinate covalent bonding. In this way, the complexed mineral is less prone to interactions with the chemical neighborhood (Miquel \& Farré, 2007).

Ferrous or ferric salts, such as $\mathrm{FeCl}_{2}, \mathrm{FeCl}_{3}$, and $\mathrm{FeSO}_{4}$, have been used to synthesize peptide-iron complexes and to study the iron-binding capacity of peptides (Caetano-Silva, Bertoldo-Pacheco, PaesLeme, \& Netto, 2015; Chaud et al., 2002; Huang, Ren, \& Jiang, 2011; Kim et al., 2007; O'Loughlin, Kelly, Murray, FitzGerald, \& Brodkorb, 2015; Ueno, Urazono, \& Kobayashi, 2014; Zhou et al., 2012). Nevertheless, to the best of our knowledge, no effort has been made to study the effect of iron sources on complex formation, even though the role of different ions on peptide and protein structure and interactions is

\footnotetext{
* Correspondence to: R.C.G. Frem, Prof. Francisco Degni 55, PO Box 355, 14800-970 Araraquara, SP, Brazil.

*** Correspondence to: F.M. Netto, Monteiro Lobato 80, 13083-862 Campinas, SP, Brazil.

E-mail addresses: elisacaetano4@gmail.com (M.E. Caetano-Silva), renata88_alves@hotmail.com (R.C. Alves), nuneslucena@mail.uft.edu.br (G.N. Lucena), rcgfrem@iq.unesp.br (R.C.G. Frem), mtb@ital.sp.gov.br (M.T. Bertoldo-Pacheco), jpallone@fea.unicamp.br (J.A. Lima-Pallone), fmnetto@unicamp.br (F.M. Netto).
} 


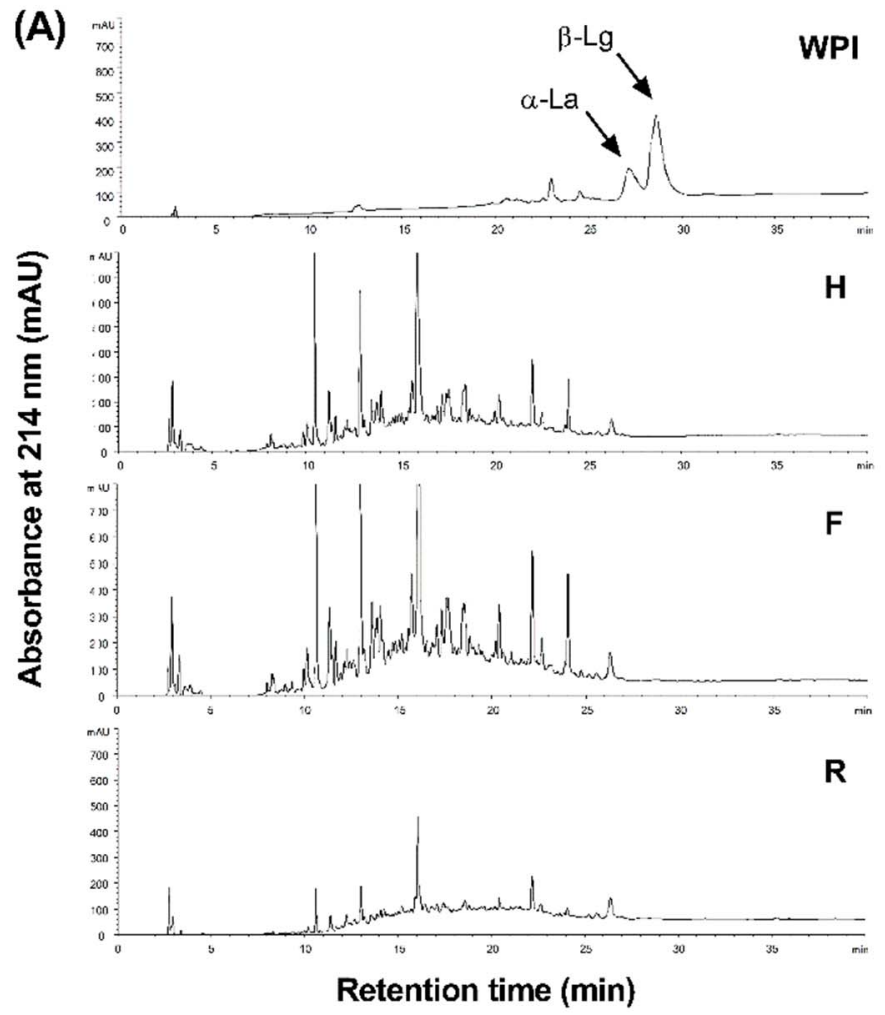

\section{Retention time ( $\mathrm{min})$}

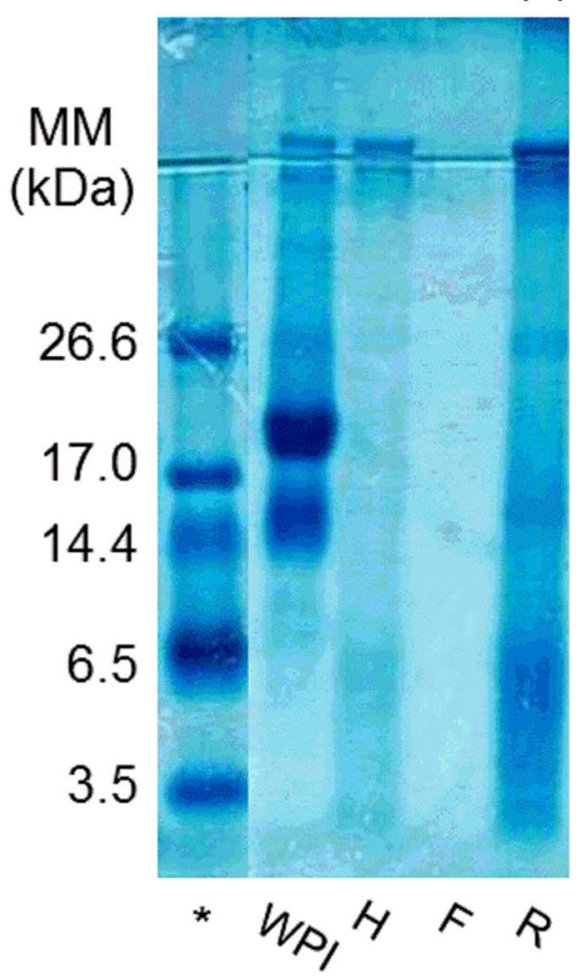

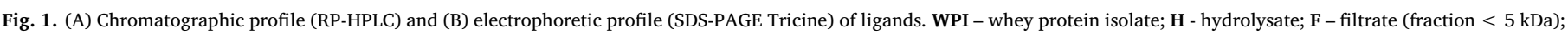
$\mathbf{R}$ - retentate (fraction $>5 \mathrm{kDa}$ ). * Molecular mass standard.

widely known (Zhang \& Cremer, 2006).

Our previous studies showed that fractions of WPI hydrolysate with pancreatin have the same iron-binding sites regardless of the molecular mass (MM) (Caetano-Silva et al., 2015); however, only complexes synthesized with low-MM peptides $(\mathrm{MM}<5 \mathrm{kDa})$ showed a capacity to increase iron uptake in vitro compared with the iron salt form. Regarding the iron source, complexes synthesized with $\mathrm{FeCl}_{2}$ led to greater ferritin synthesis than complexes synthesized with $\mathrm{FeSO}_{4}$ $(p<0.05)$ (Caetano-Silva, Cilla, Bertoldo-Pacheco, Netto, \& Alegría, 2017). Therefore, our results suggested that different iron precursors influence the functionality of the complexes due to differences in complex structure caused by the counter ions, chloride or sulfate. The aim of the present work was to test this hypothesis using peptide-iron complexes synthesized using two iron salts, $\mathrm{FeCl}_{2}$ and $\mathrm{FeSO}_{4}$, and different MM ligands to understand the effect of the iron source on the dynamics of the peptide-iron interaction, which may contribute to their future application for food fortification.

\section{Materials and methods}

\subsection{Materials}

Whey protein isolate (WPI) was obtained from Glanbia Nutritionals (Kilkenny, Ireland). Pancreatin (4xUSP, from porcine pancreas, EC 232468-9, P1750) was purchased from Sigma-Aldrich ${ }^{\circledR}$ (St. Louis, MO, USA). Iron precursors, $\mathrm{FeCl}_{2} \cdot 4 \mathrm{H}_{2} \mathrm{O}$ and $\mathrm{FeSO}_{4} \cdot 7 \mathrm{H}_{2} \mathrm{O}$, were purchased from J.T. Baker (Phillipsburg, NJ, USA) and Sigma-Aldrich ${ }^{\circledR}$ (St. Louis, MO, USA), respectively. All other chemicals and reagents used were of analytical or chromatographic grade.

\subsection{Preparation of hydrolysate and its fractions}

The hydrolysate was obtained from enzymatic hydrolysis of WPI with the enzymatic system pancreatin under previously defined conditions (Caetano-Silva et al., 2015). Briefly, WPI was diluted in deionized water $(10 \%$ protein $\mathrm{w} / \mathrm{v})$, and the reaction occurred at $\mathrm{pH}$ 8.0; it was monitored using an automatic titrator, $\mathrm{pH}$ Stat (MettlerToledo, model DL 21 Grafix, Schwerzenbach, Switzerland) with stirring and a controlled temperature $\left(40^{\circ} \mathrm{C}\right)$. After $180 \mathrm{~min}$, the enzyme was deactivated by heating $\left(85^{\circ} \mathrm{C}\right.$ for $15 \mathrm{~min}$ ), and the reaction mixture was cooled in an ice bath.

The degree of hydrolysis (DH), determined according to AdlerNissen (1986), was $16.2 \%$. The $\mathrm{pH}$ was adjusted to 6.0 with $1 \mathrm{~mol} / \mathrm{L}$ $\mathrm{HCl}$, and a portion of the reaction mass was then freeze-dried; this sample was named hydrolysate $(\mathbf{H})$. A portion of $\mathbf{H}$ was fractionated in a Pellicon ${ }^{\circledast}$ ultrafiltration system (Millipore, Bedford, MA, USA) with a cut-off membrane of $5 \mathrm{kDa}$ (Cartridge Prep/Scale - TFF $6 \mathrm{ft}^{2}$ ). The fraction with an MM $<5 \mathrm{kDa}$ was named filtrate $(\mathbf{F})$, and the one with $\mathrm{MM}>5 \mathrm{kDa}$ was named retentate (R).

\subsection{Characterization of the ligands}

\subsubsection{Chromatography}

Reversed-phase high-performance liquid chromatography (RPHPLC) was performed in an Agilent liquid chromatograph with a semipreparative and analytical quaternary pump system and a diode array detector (DAD) (Agilent, Waldbronn, Germany) on a Microsorb - MV ${ }^{\mathrm{TM}}$ $\mathrm{C}_{18}$ column (4.6 mm $\times 250 \mathrm{~mm} ; 5 \mu \mathrm{m}$ particle size) (Rainin, Woburn, MA, USA). The solvent composition was solvent A $-0.04 \%$ de TFA in ultrapure water; solvent $\mathrm{B}-0.03 \% \mathrm{TFA}$ in acetonitrile. The gradient elution conditions were solvent B from 0 to $70 \%$ in $40 \mathrm{~min}, 100 \%$ in $5 \mathrm{~min}$, and returning to $0 \%$ in 5 more min. Detection was at $214 \mathrm{~nm}$, and the sample injection volume was $50 \mu \mathrm{L}$ ( $3 \mathrm{mg}$ protein $/ \mathrm{mL}$ for $\mathbf{H}, \mathbf{F}$, and $\mathbf{R}$, and $1 \mathrm{mg}$ protein/mL for WPI). The proteins, $\alpha$-lactoalbumin ( $\alpha$ La) and $\beta$-lactoglobulin ( $\beta$-Lg), from bovine milk (Sigma-Aldrich ${ }^{\circledR}$, St. Louis, MO, USA), were used as standards. 

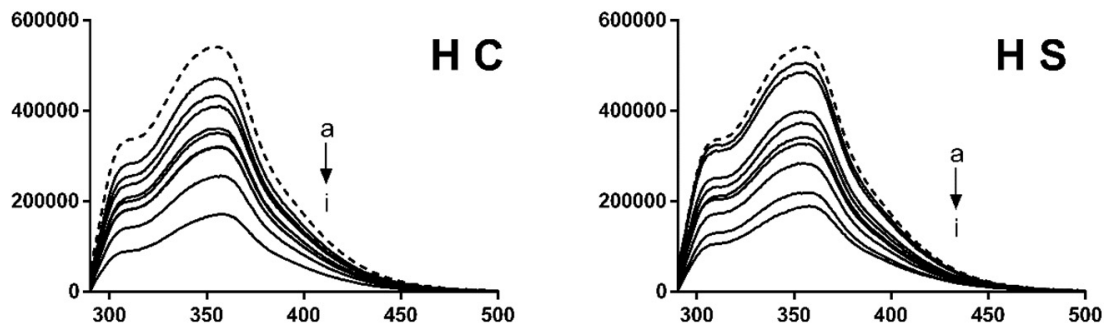

Fig. 2. Fluorescence emission spectra of ligands $\mathbf{H}$ - hydrolysate; $\mathbf{F}$ - filtrate (fraction $<5 \mathrm{kDa}$ ); $\mathbf{R}$ - retentate (fraction $>5 \mathrm{kDa}$ ); WPI - whey protein isolate $(5 \mathrm{mg}$ protein $/ \mathrm{mL}$ ) without iron addition (dashed lines) and with addition of $\mathbf{C}-\mathrm{FeCl}_{2}$ or $\mathbf{S}-\mathrm{FeSO}_{4}$ (full lines) in different iron:protein ratios. (a-i) $10 ; 20 ; 30 ; 40 ; 60 ; 80 ; 100 ; 200$ $400 \mu \mathrm{mol} \mathrm{Fe} / \mathrm{g}$ protein. Excitation wavelength: $280 \mathrm{~nm}$; emission wavelength: $290-500 \mathrm{~nm}$.
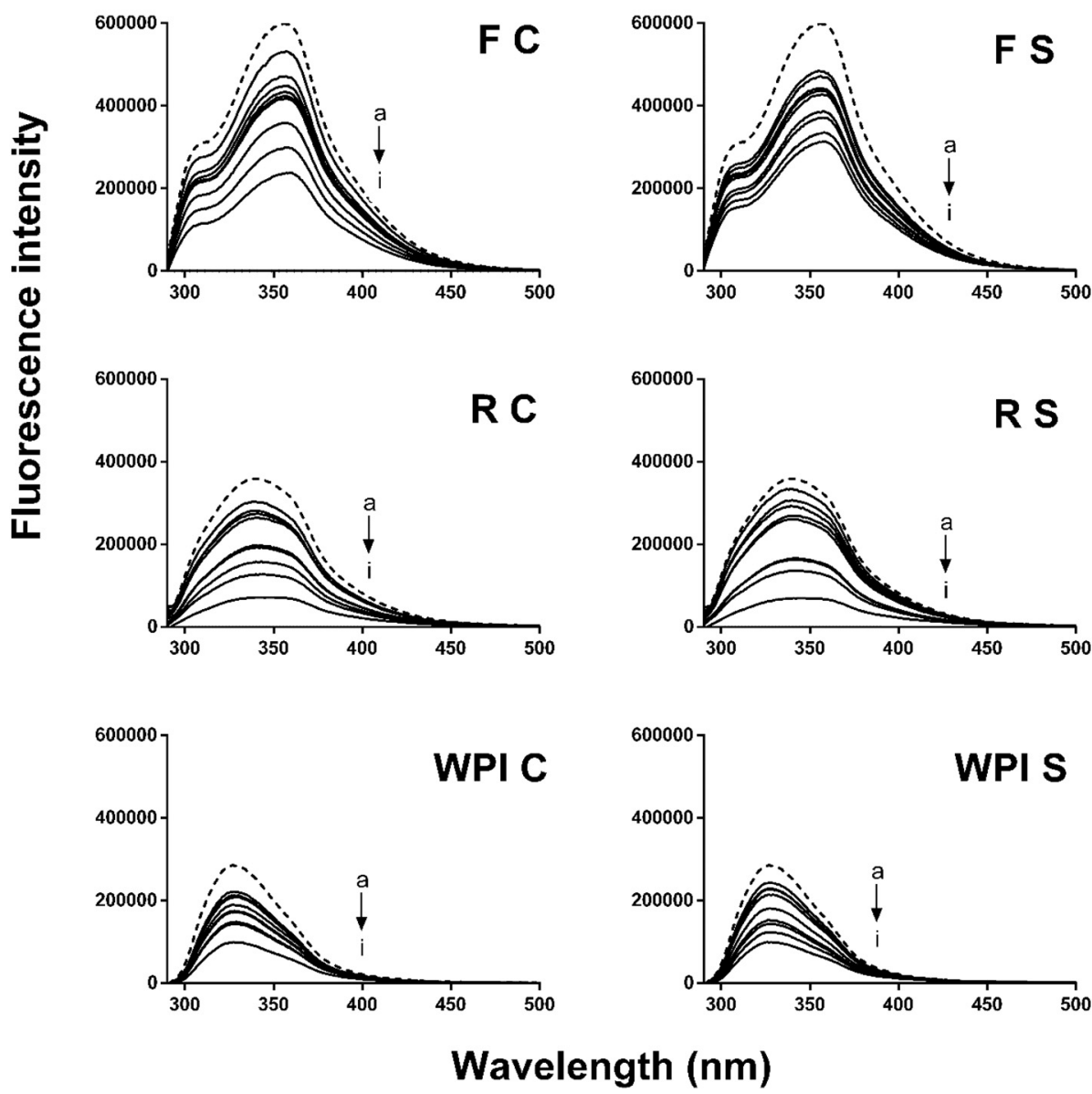

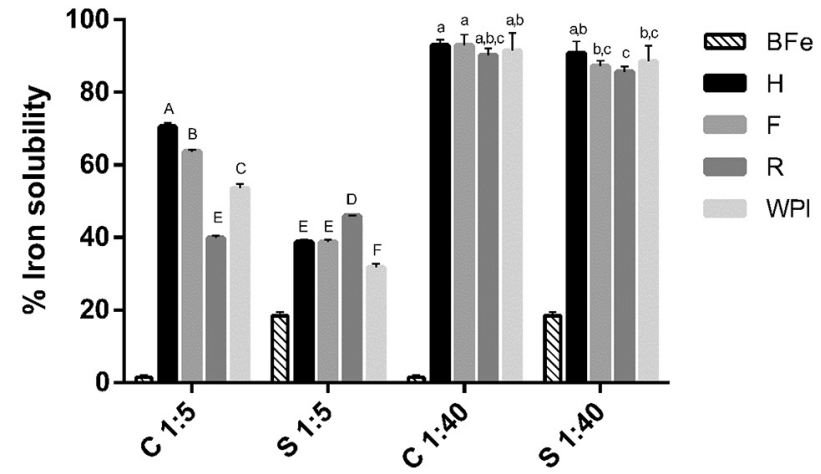

Fig. 3. Iron solubility (\%) after complexes synthesis (pH 7.0) under ratio iron:protein (w/ w) of 1:40 or 1:5 with $\mathrm{FeCl}_{2}$ (C) or $\mathrm{FeSO}_{4}$ (S). BFe - control assay with only iron salt; $\mathbf{H}$ hydrolysate; $\mathbf{F}$ - filtrate (fraction $<5 \mathrm{kDa}$ ); $\mathbf{R}$ - retentate (fraction $>5 \mathrm{kDa}$ ); WPI - whey protein isolate. * samples with different letters are statistically different $(p<0.05)$; controls assays (BFe C e BFe S) are not included in the statistical analysis ANOVA and Tukey.

\subsubsection{Electrophoresis}

The electrophoretic profiles were obtained using the SDS-PAGE Tricine system according to Schagger (2006) with a separation gel containing $16 \%$ acrylamide and $6 \mathrm{~mol} / \mathrm{L}$ urea and with resolving and stacking gels containing $10 \%$ and $4 \%$ of acrylamide, respectively. Ligands were diluted $(1 \%$ protein $\mathrm{w} / \mathrm{v})$ in reducing buffer $(0.5 \mathrm{~mol} / \mathrm{L}$ Tris-HCl, pH 6.8, 10\% SDS, $10 \%$ glycerol, $5 \% \beta$-mercaptoethanol and $0.1 \%$ Coomassie Blue G250) and heated at $90{ }^{\circ} \mathrm{C}$ for 5 min. Aliquots of $10 \mu \mathrm{L}$ of each sample were subsequently loaded onto the gels. The MM of the peptides was estimated using a 3.5-26 kDa marker kit (Bio-Rad, Hercules, CA, USA) as the standard.

\subsection{Intrinsic fluorescence spectroscopy}

Intrinsic fluorescence emission spectra of the ligands $\mathbf{H , ~} \mathbf{F}, \mathbf{R}$, and WPI with the addition of different amounts of iron from $\mathrm{FeCl}_{2}$ or $\mathrm{FeSO}_{4}$ $(0-2 \mathrm{mmol} \mathrm{Fe} / \mathrm{L})$ were obtained using a multifrequency phase ISS $\mathrm{K} 2$ fluorometer (Champaign, IL, USA). The excitation wavelength was $280 \mathrm{~nm}$, and emission wavelengths ranging from 290 to $500 \mathrm{~nm}$ were recorded. To this end, stock solutions of iron salts ( $6 \mathrm{mmol} \mathrm{Fe} / \mathrm{L})$ and/ 
Table 1

Main absorption bands in the infrared and tentative assignments of the corresponding vibrational modes of free ligands $(\mathbf{H}$, hydrolysate; F, filtrate; $\mathbf{R}$, retentate and WPI, whey protein isolate) and their respective iron complexes, obtained from $\mathrm{FeCl}_{2}(-\mathrm{Fe} \mathbf{C})$ or $\mathrm{FeSO}_{4}(-\mathrm{Fe} \mathrm{S}$ )

Sources for assignment to vibrational modes: (Acevedo-Chávez, Costas, Bernès, Medina, \& Gasque, 2002; Barth, 2007; Benaki et al., 1998; Berova, Polavarapu, Nakanishi, \& Woody, 2012; Chaud et al., 2002; Eckert et al., 2016; Huang et al., 2011; Kaiden, Matsui, \& Tanaka, 1987; Krimm \& Bandekar, 1986; Lee et al., 2015; Mukherjee, Chowdhury, \& Gai, 2007; Nakamoto, 2009; O'Loughlin et al., 2015; Prigogine \& Rice, 2009; Trivedi \& Vasudevan, 2007).

\begin{tabular}{|c|c|c|c|c|}
\hline \multicolumn{4}{|c|}{ IR bands (wavenumber, $\mathrm{cm}^{-1}$ ) } & \multirow{2}{*}{$\begin{array}{l}\text { Tentative } \\
\text { assignment }\end{array}$} \\
\hline $\mathrm{H}$ & $\mathrm{F}$ & $\mathrm{R}$ & WPI & \\
\hline $3437 s, b r$ & $3427 s, b r$ & $3432 s, b r$ & $3411 s, b r$ & $\nu \mathrm{O}-\mathrm{H}$ \\
\hline $3268 v w$ & $3268 v w$ & - & $3285 s$ & Amide $\mathrm{A}(\nu \mathrm{N}-\mathrm{H})$ \\
\hline $2967 v w, 2927 v w$ & $\begin{array}{l}2964 v w \\
2930 v w\end{array}$ & - & $\begin{array}{l}2960 v w \\
2927 v w\end{array}$ & $\nu \mathrm{C}_{\text {aliphatic }}-\mathrm{H}$ \\
\hline $1632 s$ & $1632 s$ & $1632 s$ & $1632 s$ & Amide $\mathrm{I}(\nu \mathrm{C}=\mathrm{O})$ \\
\hline $1592 s$ & $1592 s$ & $1592 s$ & $1552 w$ & Amide II \\
\hline $1385 m, 1344 w$ & $\begin{array}{l}1385 m \\
1344 w\end{array}$ & $\begin{array}{l}1385 m \\
1344 w\end{array}$ & $\begin{array}{l}1380 m \\
1344 w\end{array}$ & Amide III \\
\hline $1110 w, 1039 v w$ & $\begin{array}{l}1110 w \\
1039 v w\end{array}$ & $1100 v w, b r$ & $1110 v w, b r$ & $\nu \mathrm{O}-\mathrm{C}$ \\
\hline- & $1077 v w$ & - & $1085 v w$ & $\delta \mathrm{C}-\mathrm{H}$ \\
\hline- & $989 w$ & - & $990 w$ & $\nu \mathrm{C}-\mathrm{C}-\mathrm{N}$ \\
\hline $\mathrm{H}-\mathrm{Fe} \mathrm{C}$ & $\mathrm{F}-\mathrm{Fe} \mathrm{C}$ & $\mathrm{R}-\mathrm{Fe} \mathrm{C}$ & WPI-Fe C & \\
\hline $3401 s, b r$ & $3406 s, b r$ & $3386 s, b r$ & $3411 s, b r$ & $\nu \mathrm{O}-\mathrm{H}$ \\
\hline $3268 v w$ & $3268 v w$ & - & $3272 w$ & Amide $\mathrm{A}(\nu \mathrm{N}-\mathrm{H})$ \\
\hline $3065 w$ & $3066 w$ & - & $3062 w$ & $\nu \mathrm{C}_{\text {aromatic }}-\mathrm{H}$ \\
\hline $2965,2927 v w$ & $\begin{array}{l}2964 \\
2932 v w\end{array}$ & - & $\begin{array}{l}2966 \\
2927 v w\end{array}$ & $\nu \mathrm{C}_{\text {aliphatic }}-\mathrm{H}$ \\
\hline $1653 s, b r$ & $1653 s, b r$ & $1653 s$ & $1651 s$ & $\begin{array}{l}\text { Amide I } \\
+v_{\text {as }} \mathrm{COO}-\mathrm{Fe}\end{array}$ \\
\hline $1540 m$ & $1540 m$ & $1539 s$ & $1532 w$ & Amide II \\
\hline $1431 s$ & $1431 s$ & $1431 s$ & - & $\nu_{\mathrm{s}} \mathrm{COO}-\mathrm{Fe}$ \\
\hline $1344 v w$ & $1344 v w$ & - & - & Amide III \\
\hline $1117 v w$ & $1117 v w$ & $1109 v w$ & $1114 v w$ & $\nu \mathrm{O}-\mathrm{C}-\mathrm{Fe}$ \\
\hline $1073 v w$ & $1073 v w$ & - & $1070 v w$ & $\delta \mathrm{C}-\mathrm{H}$ \\
\hline $\mathrm{H}-\mathrm{Fe} \mathrm{S}$ & $\mathrm{F}-\mathrm{Fe} \mathrm{S}$ & $\mathrm{R}-\mathrm{Fe} \mathrm{S}$ & WPI-Fe S & \\
\hline $\begin{array}{l}3554 s h, 3474 s h, \\
\quad 3414 s\end{array}$ & $\begin{array}{l}3554 s h \\
3474 s h \\
3414 s\end{array}$ & $3414 s, b r$ & $3419 s, b r$ & $\nu \mathrm{O}-\mathrm{H}+\mathrm{H}$-bonds \\
\hline $3248 w$ & $3248 w$ & - & - & Amide $\mathrm{A}(\nu \mathrm{N}-\mathrm{H})$ \\
\hline $2967,2927 v w$ & $\begin{array}{l}2966, \\
2928 v w\end{array}$ & - & $\begin{array}{l}2968, \\
2927 v w\end{array}$ & $\nu \mathrm{C}_{\text {aliphatic }}-\mathrm{H}$ \\
\hline $1640 s, 1621 w$ & $\begin{array}{l}1640 s \\
1619 w\end{array}$ & $1641 s$ & $1641 s$ & $\begin{array}{l}\text { Amide I } \\
+v_{\text {as }} \mathrm{COO}-\mathrm{Fe}\end{array}$ \\
\hline $1556 v w$ & $1555 v w$ & $1543 s$ & $1542 w$ & Amide II \\
\hline $1431 v w$ & $1431 w$ & - & - & $\nu_{\mathrm{s}} \mathrm{COO}-\mathrm{Fe}$ \\
\hline $1385 w$ & $1385 w$ & $1385 w$ & 1380 & Amide III \\
\hline $1146 s$ & $1150 s$ & $1149 s$ & $1144 s$ & $\mathrm{SO}_{4}{ }^{2-}$ \\
\hline $1114 v w$ & $1115 v w$ & $1122 v w$ & $1120 v w$ & $\nu \mathrm{O}-\mathrm{C}-\mathrm{Fe}$ \\
\hline $993 w$ & $994 v w$ & $996 w$ & - & $\nu \mathrm{C}-\mathrm{C}-\mathrm{N}$ \\
\hline $627 m$ & $624 m$ & $624 w$ & $619 w$ & $\mathrm{SO}_{4}^{2-}$ \\
\hline
\end{tabular}

$s=$ strong; $b r=$ broad $s h=$ shoulder; $w=$ weak; $v w=$ very weak; $m=$ medium

or ultrapure water were mixed with stock solutions of the ligands $(7.5 \mathrm{mg}$ protein $/ \mathrm{mL})$ to reach protein content of $5 \mathrm{mg} / \mathrm{mL}$ and iron:protein ratios of: $0,10,20,30,40,60,80,100,200$, and $400 \mu \mathrm{mol} \mathrm{Fe} / \mathrm{g}$ protein. After $5 \mathrm{~min}$ of iron addition, the fluorescence emission spectra were obtained as a plot of the fluorescence intensity versus wavelength (nm) (Lakowicz, 2006). Ten spectra were obtained for each ligand with different iron:protein ratios. All spectra were corrected for blank emission.

\subsection{Synthesis of peptide-iron complexes and their iron-binding capacities}

Hydrolysate $(\mathbf{H})$ and its fractions $\mathbf{F}$ and $\mathbf{R}$ were used as ligands to synthesize the iron complexes. WPI was also studied as a ligand to compare the complexes synthesized with the whole protein. The iron precursor compounds were $\mathrm{FeCl}_{2} \cdot 4 \mathrm{H}_{2} \mathrm{O}$ or $\mathrm{FeSO}_{4} \cdot 7 \mathrm{H}_{2} \mathrm{O}$. The reactions were conducted under the same conditions used in previous studies
(Caetano-Silva et al., 2015; Caetano-Silva et al., 2017) with an iron:protein ratio of $1: 40(\mathrm{w} / \mathrm{w})$ and $1: 5(\mathrm{w} / \mathrm{w})$, which is equivalent to 450 and $3600 \mu \mathrm{mol}$ of $\mathrm{Fe} / \mathrm{g}$ protein, respectively. The iron concentration was fixed at $0.1 \%(\mathrm{w} / \mathrm{v})$, whereas the protein concentrations were $4 \%(\mathrm{w} / \mathrm{v})$ and $0.5 \%(\mathrm{w} / \mathrm{v})$. Briefly, ligand solutions were adjusted to $\mathrm{pH} 7.0$ to favor deprotonation of the iron-binding sites (Porath, 1990), and the iron salt was added. The $\mathrm{pH}$ of each reaction medium was monitored and adjusted every $15 \mathrm{~min}$. After $1 \mathrm{~h}$ of reaction with stirring $\left(25 \pm 2{ }^{\circ} \mathrm{C}\right.$ ), the suspensions were centrifuged (5000 $\mathrm{g}$ for $20 \mathrm{~min}$ ) (Sorvall Instruments DuPont, RC5C, Wilmington, USA) and filtered through filter paper (Whatman $\mathrm{n}^{\circ} 1$ ). The iron content was determined in the supernatants via atomic absorption spectrophotometry (AAS) according to Boen, Soeiro, Pereira-Filho, and Lima-Pallone (2008) on a Perkin-Elmer Analyst 300 spectrometer (Norwalk, CT, USA) equipped with a deuterium lamp background corrector. Prior to iron determination, all samples were subjected to acid digestion with concentrated nitric acid and hydrogen peroxide $(2: 1 \mathrm{v} / \mathrm{v})$ at $110^{\circ} \mathrm{C}$ for $2 \mathrm{~h}$ and transferred quantitatively to volumetric flasks of 25 or $50 \mathrm{~mL}$, and the volumes were completed with ultrapure water. All experiments were performed in triplicate. The iron content was measured using a hollow cathode lamp for iron $(248.3 \mathrm{~nm})$. The standard curve ranged from 0.2 to $2.6 \mathrm{mg} \mathrm{Fe} / \mathrm{L}$.

The iron-binding capacity (\%) was calculated as the iron solubility in the supernatant with respect to the Fe initially added (Eq. (1)).

Iron - binding capacity $(\%)=\frac{\text { Fe supernatant }}{\text { Fe initial }} \times 100$

The supernatants containing the complexes were freeze-dried and stored frozen $\left(-18^{\circ} \mathrm{C}\right)$. The iron complexes with $\mathbf{H}, \mathbf{F}, \mathbf{R}$, and WPI were named $\mathbf{H}-\mathbf{F e}, \mathbf{F}-\mathbf{F e}, \mathbf{R}-\mathbf{F e}$, and WPI-Fe, respectively. The iron source was expressed with the letters $\mathbf{C}$ or $\mathbf{S}$ for $\mathrm{FeCl}_{2}$ or $\mathrm{FeSO}_{4}$, respectively.

\subsection{Characterization of the complexes}

Ligands and ligand-iron complexes were analyzed via infrared (IR) spectroscopy. This technique is based on radiation absorption due to the vibration between molecular atoms (Haris \& Chapman, 1995), and it has been used to obtain information about the chemical composition and conformational structure of proteins and peptides. Samples $(2 \mathrm{mg})$ were mixed with dry $\mathrm{KBr}$ and compressed in a compact disc. The vibrational spectra were recorded on an FT-IR spectrometer (Nicolet iS5, Thermo Fisher Scientific, Waltham, MA, USA) in a spectral range from 4000 to $400 \mathrm{~cm}^{-1}$ with 32 scans and at a resolution of $2 \mathrm{~cm}^{-1}$. Spectra were analyzed using the data analysis software, Origin 8.3 (Microcal Software, Inc., One Roundhouse Plaza, Northampton, MA, USA).

Ligand $\mathbf{F}$ and its respective complexes, $\mathbf{F}-\mathbf{F e} \mathbf{C}$ and $\mathbf{F}-\mathbf{F e} \mathbf{S}$, were selected to be analyzed via thermal analyses concerning the influence of using different iron precursors. Thermogravimetry (TG) and differential thermal analysis (DTA) curves were obtained using a TA Instruments model SDTQ600 under a flow of dry synthetic air $\left(150 \mathrm{~mL} \mathrm{~min}^{-1}\right)$, at a temperature up to $1000{ }^{\circ} \mathrm{C}$, and at a heating rate of $10^{\circ} \mathrm{C} \min ^{-1}$ in $\alpha$ alumina sample holders.

\subsection{Statistical analysis}

The results of the iron determination were expressed as the means \pm standard deviation and were statistically analyzed using the statistical package, GraphPad Prism 6 (GraphPad Software Inc., La Jolla, USA) via one-way analysis of variance (ANOVA). For significant differences between samples (Fcalc $>$ Ftab), the means were compared via post hoc Tukey's test. Values of $p<0.05$ were considered to be significant. 

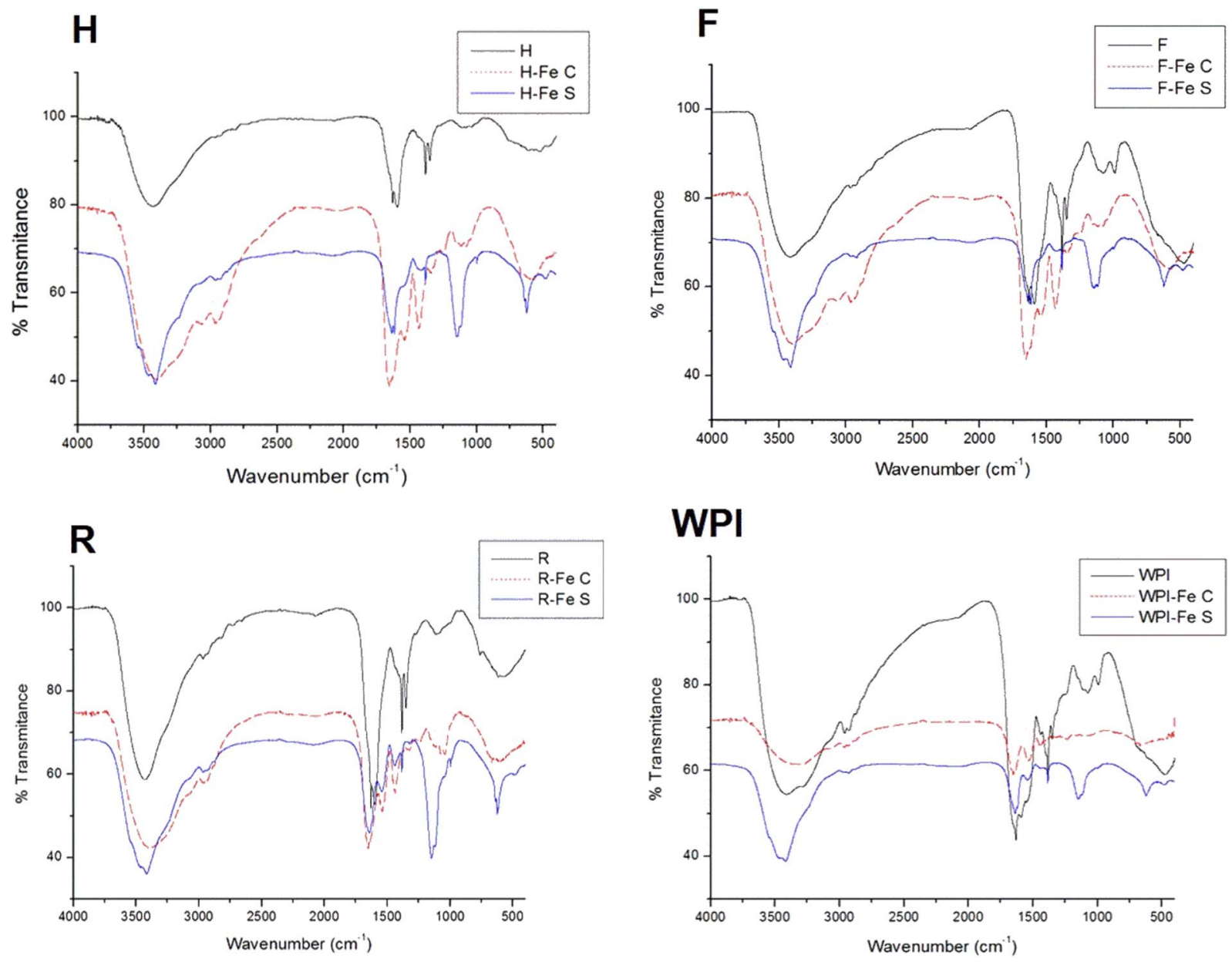

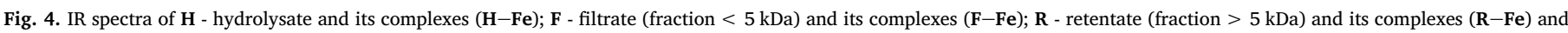
WPI - whey protein isolate and its complexes (WPI-Fe) synthesized from $\mathrm{FeCl}_{2}(-\mathbf{F e} \mathbf{C})$ or $\mathrm{FeSO}_{4}(-\mathbf{F e} \mathbf{S})$.

\section{Results and discussion}

\subsection{Characterization of the ligands}

The proteins, $\alpha$-lactoalbumin ( $\alpha$-La) e $\beta$-lactoglobulin ( $\beta$-Lg), were used as standards for RP-HPLC analysis, and showed retention times (RT) of 27.2 and $28.0 \mathrm{~min}$, respectively. The chromatographic (RPHPLC) profile of $\mathbf{H}$ and its fractions $\mathbf{F}$ and $\mathbf{R}$ (Fig. 1A) showed the absence of $\alpha$-La and $\beta$-Lg peaks that were observed in the WPI profile, indicating that these proteins were hydrolyzed to smaller and more hydrophilic fragments. The profiles of $\mathbf{H}$ and $\mathbf{F}$ (Fig. 1A) are similar to each other, and the majority of peptides eluted in the high (RT $<10$ $\mathrm{min}$ ) and medium (10 $\mathrm{min}<\mathrm{RT}<20 \mathrm{~min})$ hydrophilicity regions. On the other hand, the profile of $\mathbf{R}$ showed a lower number of peaks than the other ligands.

The electrophoretic (SDS-PAGE Tricine) profiles (Fig. 1B) showed differences in the MM values among the ligands. No band was observed in the profile of $\mathbf{F}$, possibly due to the presence of peptides with an MM $<3 \mathrm{kDa}$, which were not dyed by Coomassie Blue (Krohn, 2001). The profile of $\mathbf{H}$ showed the disappearance of $\alpha-\mathrm{La}(14.2 \mathrm{kDa})$ and $\beta-\mathrm{Lg}$ $(18.4 \mathrm{kDa})$, which were both present in the WPI profile, due to the hydrolysis of these proteins to peptides of lower MM.

In the literature, there are some discrepancies regarding the ironbinding capacity of peptides with different MM values: the iron-binding capacity to peptides with a MM of $10-30 \mathrm{kDa}$ (Lv et al., 2009) or to peptides with MM $<1 \mathrm{kDa}$ (O'Loughlin et al., 2015) has been reported to be higher. The ligands showed differences in MM and hydrophilicity, which may lead to a different capacity of the free iron to access the iron-binding sites, possibly resulting in different complexes.

\subsection{Intrinsic fluorescence spectroscopy}

The fluorescence emission spectra of the ligands with no addition of the iron salt and after the interaction with the metal in various concentrations $(10,20,30,40,60,80,100,200$, and $400 \mu \mathrm{mol} \mathrm{Fe} / \mathrm{g}$ protein) are shown in Fig. 2 . The $\lambda_{\max }$ of the ligands ranged from 310 to $350 \mathrm{~nm}$, which is in accordance with the emission range of tryptophan (Trp) (Adams et al., 2002). The fluorescence emission spectra of $\mathbf{H}$ and the fractions $\mathbf{F}$ and $\mathbf{R}$ showed a higher intensity and a redshift of the $\lambda_{\max }\left(\lambda_{\max }\right.$ shifted to longer wavelengths) compared with the WPI spectra (Fig. 2 and Supplementary data, Table S1), suggesting that structural changes affected Trp upon hydrolysis (Zhou et al., 2012). The hydrolysis process yielded fragments with a lower MM and, as a result, a rearrangement occurred and the microenvironment of these residues could be changed. The fluorescence emission spectra of $\mathbf{H}$ and $\mathbf{F}$ showed differences in relation to the $\mathbf{R}$ spectra possibly due to differences in the peptide profiles, as observed in the chromatographic and electrophoretic profiles (Fig. 1).

The fluorescence intensity of all ligands at a fixed amount of protein $(5 \mathrm{mg} / \mathrm{mL})$ decreased up to $70 \%$ with iron addition regardless of the iron source. For all ligands, the highest iron:protein ratio $(400 \mu \mathrm{mol} \mathrm{Fe} /$ $\mathrm{g}$ protein) led to the lowest fluorescence intensity. Iron interaction with iron-binding sites, especially carboxyl groups, may change Trp fluorescence depending on the impact of this interaction on the peptide/ protein conformation (Lakowicz, 2006), since the $\operatorname{Trp} \lambda_{\max }$ and quantum yield (total intensity) are sensitive to the local electrostatic 

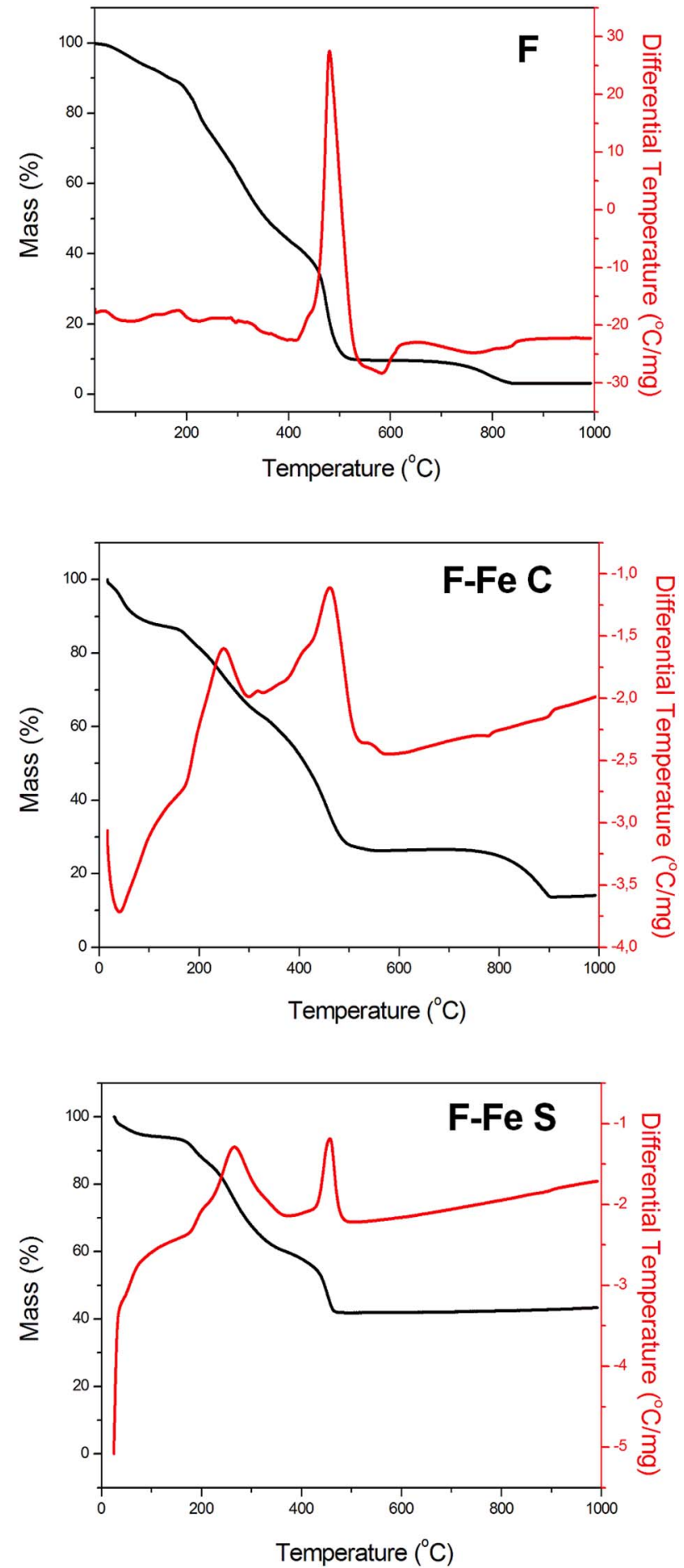

Fig. 5. TG and DTA curves of filtrate (fraction $<5 \mathrm{kDa}$ ) (F) and respective complexes synthesized with $\mathrm{FeCl}_{2}(\mathbf{F}-\mathbf{F e} \mathbf{C})$ or $\mathrm{FeSO}_{4}(\mathbf{F}-\mathbf{F e} \mathbf{S})$.

environment (Callis, 2014; Mach \& Middaugh, 1994). The decrease in fluorescence intensity after iron addition may therefore be explained by the changes in peptide conformations as a consequence of iron-peptide interactions (Adams et al., 2002), which may transfer Trp residues to the surface of the molecule during complexation with iron (Zhou et al., 2012).

Other factors, such as ionic strength, may affect the conformation of the ligands (Dominy, Perl, Schmid, \& Brooks, 2002) and interfere with their iron-binding capacity. The ionic strength of the reaction mixture increases up to $300 \%$ from 10 to $400 \mu \mathrm{mol} \mathrm{Fe} / \mathrm{g}$ protein. At the same iron:protein ratio, the ionic strengths of reaction mixtures with $\mathrm{FeSO}_{4}$ are approximately $30 \%$ higher than with $\mathrm{FeCl}_{2}$. The salts affect the stability of proteins by modifying the ionic strength of the solution (Dominy et al., 2002), and they can exert specific effects on proteins that depend on the nature of the salt and its concentration, resulting in either stabilization or destabilization (Arakawa \& Timasheff, 1984). The counter ions $\left(\mathrm{SO}_{4}{ }^{-2}\right.$ and $\mathrm{Cl}^{-}$) have different positions in the Hofmeister series (Zhang \& Cremer, 2006), differing in their capacity to influence the protein stability and protein-protein interaction. The sulfate ion is larger than chloride and exerts an aggregation effect on proteins (salting out), whereas chloride ions exhibit a more solubilizing effect than $\mathrm{SO}_{4}{ }^{-2}$ (salting in) (Zhang \& Cremer, 2006). Thus, the complexes could show differences regarding the conformation of peptides during their formation (see the below Infrared discussion).

\subsection{Synthesis of peptide-iron complexes and their iron-binding capacities}

Fig. 3 shows the iron-binding capacity expressed as iron solubility (\%) at $\mathrm{pH} 7.0$ after the synthesis of the complexes for both iron:protein ratios of 1:40 and 1:5. The low iron solubility observed in the control samples with iron salts (BFe) $\left(1.5 \%\right.$ for $\mathrm{FeCl}_{2}$ and $18.4 \%$ for $\left.\mathrm{FeSO}_{4}\right)$ is due to ferric hydroxide formation, which is insoluble at this $\mathrm{pH}$. The synthesis reaction led to an increase in iron solubility, suggesting that all ligands exhibited an iron-binding capacity regardless of their MM, which is in accordance with the results obtained by other authors (Guo et al., 2013; Lv, Guo, Tako, \& Glahn, 2014; Wu, Liu, Zhao, \& Zeng, 2012). At a ratio of $1: 40$, complexes with $\mathrm{FeCl}_{2}$ showed iron solubilities similar to those of $\mathrm{FeSO}_{4}$ at 84 to $93 \%$, which is possibly due to a large number of available iron-binding sites. At a ratio of 1:5, synthesis with $\mathrm{FeCl}_{2}$ led to an iron solubility that was significantly higher than with $\mathrm{FeSO}_{4}$, and led to greater differences among the ligands than with $\mathrm{FeSO}_{4}$ (Fig. 3). The low iron solubility at this ratio ranging from $32 \%$ to $70 \%$ is related to the low peptide concentration of the synthesis mixture in relation to the iron concentration and the consequent low availability of iron-binding sites. At this ratio, $\mathrm{pH}$ instability of the reaction medium was observed ( 7.0 to 5.8 in $15 \mathrm{~min}$ ). This $\mathrm{pH}$ drop during the synthesis reaction may have changed the protonated state of the iron-binding sites, hindering the iron interaction with the peptides. Therefore, part of the iron ions formed $\mathrm{FeOH}$.

\subsection{Characterization of the complexes}

The IR spectra of the complexes synthesized with an iron:protein ratio of 1:40 showed no detectable difference from the spectra of the corresponding free ligand (data not shown). The high proportion of unbound peptides may have overlapped shifts induced by iron binding, hindering the observation of relevant information. Spectra of the complexes synthesized with an iron:protein ratio of 1:5 enabled IR spectral evaluation due to the differences observed in relation to the spectra of the free ligands.

Table 1 shows the main absorption bands in the infrared spectra and the assignments of the corresponding vibrational modes of the free ligands and the peptide-iron complexes.

Concerning the free ligands, several differences were observed in the vibrational spectrum of WPI in relation to H, F, and R. For instance, the Amide II band can be observed as a strong band at $1592 \mathrm{~cm}^{-1}$ in the spectra of the peptide ligands (H, F, and $\mathbf{R}$ ) and at $1552 \mathrm{~cm}^{-1}$ in the WPI spectrum (Prigogine \& Rice, 2009) (Table 1). The Amide II band shows the breaking of peptide bonds during the hydrolysis process since this band is dependent on secondary conformations, and its position for intact protein and peptides is different (Prigogine \& Rice, 2009).

Regardless of the iron precursor compound $\left(\mathrm{FeCl}_{2}\right.$ or $\left.\mathrm{FeSO}_{4}\right)$ or the ligand, in general, the interactions of the divalent metallic ion and the ligands led to the formation of orange species, which is the characteristic color of iron(III) compounds. The synthesis reaction conditions lead to the conversion of ferrous to the ferric form due to the presence 
Table 2

Initial and final temperatures $\left({ }^{\circ} \mathbf{C}\right)$, partial mass losses (\%), and DTA peaks $\left({ }^{\circ} \mathrm{C}\right)$ of filtrate $(\mathbf{F})$ and the corresponding peptide-iron complexes, $\mathbf{F}-\mathbf{F e} \mathbf{C}$ and $\mathbf{F}-\mathbf{F e} \mathbf{S}$.

\begin{tabular}{|c|c|c|c|c|c|c|}
\hline \multirow[t]{2}{*}{ Compound } & \multirow[t]{2}{*}{ Step } & \multirow[t]{2}{*}{$\Delta \mathrm{T}\left({ }^{\circ} \mathrm{C}\right)$} & \multirow[t]{2}{*}{$\Delta \mathrm{m}(\%)$} & \multicolumn{2}{|c|}{ DTA peaks $\left({ }^{\circ} \mathrm{C}\right)$} & \multirow[t]{2}{*}{ Assignments } \\
\hline & & & & Endo & Exo & \\
\hline \multirow[t]{3}{*}{$\mathbf{F}$} & 1 & $22-417$ & 57.4 & 83.5 & 183.4 & Water evaporation and combustion \\
\hline & 2 & $417-558$ & 32.2 & - & 480.4 & Sample decomposition from rupture of polypeptide bonds, forming carbonaceous material \\
\hline & 3 & $558-876$ & 7.0 & - & - & Decomposition of carbonaceous material \\
\hline \multirow[t]{4}{*}{ F-Fe C } & 1 & $17-118$ & 12.4 & 40.4 & - & Water evaporation \\
\hline & 2 & $118-331$ & 24.9 & 170.4 & 249.1 & Coordinated water liberation and rupture of peptide-Fe bonds \\
\hline & 3 & $331-577$ & 35.7 & - & 461.9 & Rupture of polypeptide bonds and formation of $\mathrm{Fe}_{2} \mathrm{O}_{3}$ \\
\hline & 4 & $761-906$ & 13.3 & - & - & Decomposition of carbonaceous material \\
\hline \multirow[t]{3}{*}{ F-Fe $S$} & 1 & $25-156$ & 6.6 & 42.6 & - & Water evaporation \\
\hline & 2 & $156-348$ & 31.8 & 171.5 & 265.1 & Coordinated water liberation and rupture of peptide-Fe bonds \\
\hline & 3 & $348-476$ & 19.3 & - & 456.6 & Rupture of polypeptide bonds and formation of $\mathrm{Fe}_{2} \mathrm{O}_{3}$ \\
\hline
\end{tabular}

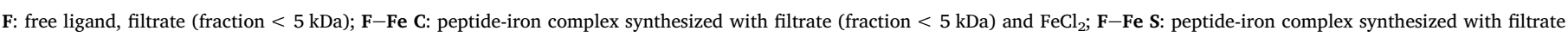
(fraction $<5 \mathrm{kDa}$ ) and $\mathrm{FeSO}_{4}$.
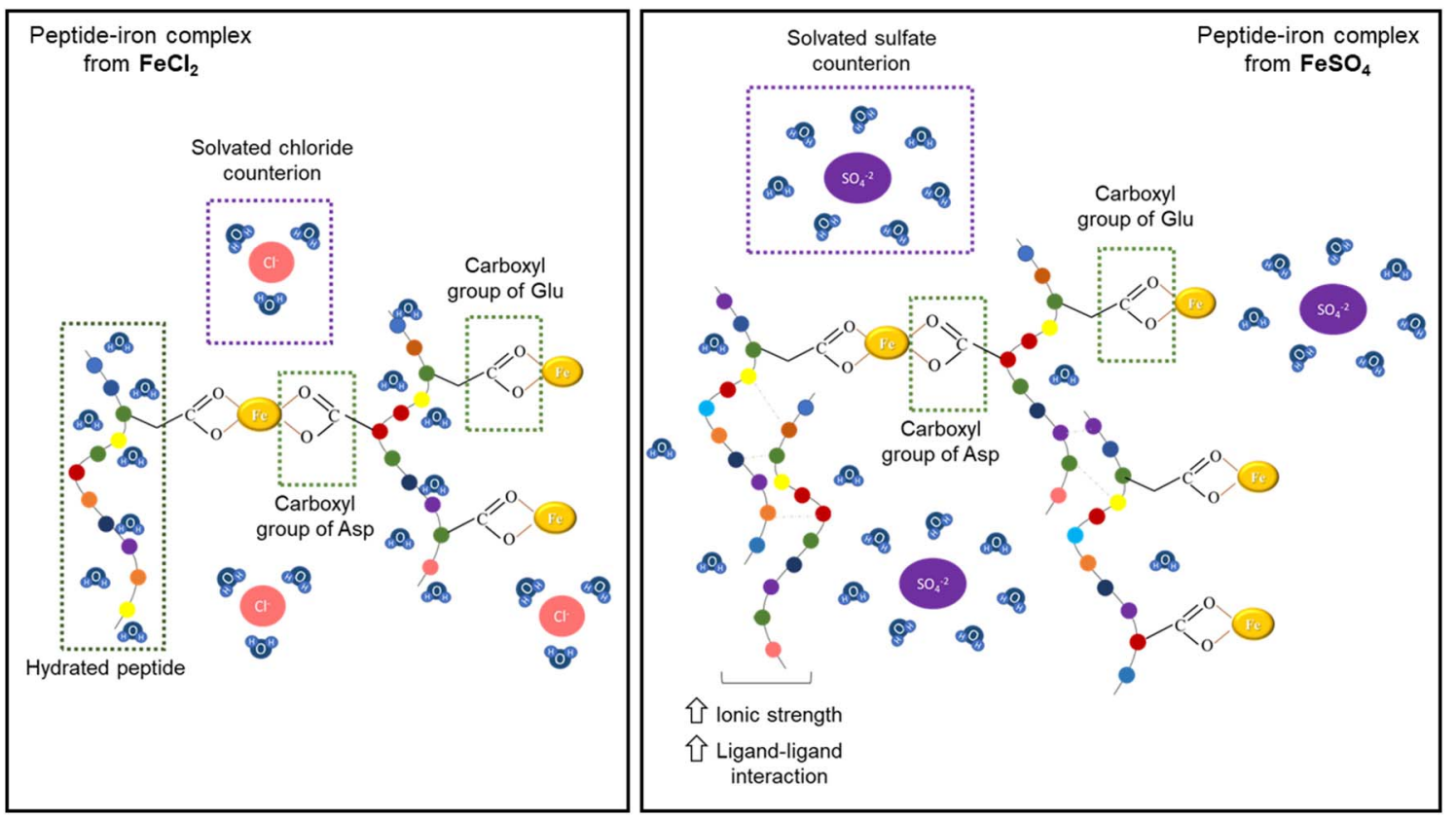

Fig. 6. Simplified model of peptide-iron complexes.

of oxygen. This conversion may favor the formation of the complexes, since, as a hard acid, $\mathrm{Fe}^{3+}$ forms high-affinity complexes with hard oxygen ligands as carboxyl groups. Thus, the thermodynamic preference of these groups can be for $\mathrm{Fe}^{3+}$ instead of for di-cationic metal ions (Haas \& Franz, 2009), which suggests that the majority of the complexes were formed with iron ions in the ferric form.

Both IR and TG/DTA techniques were used to characterize the peptide-iron complexes and allowed inference of some important aspects, which are divided into two main topics: (I) iron coordination by the ligands and (II) the influence of the iron precursor compounds, which will be discussed in detail.

(I) Iron coordination by the ligands

The Amide I band is originated primarily from the peptide $\mathrm{C}=\mathrm{O}$ stretching vibration mode and was observed at $1632 \mathrm{~cm}^{-1}$ (Mukherjee et al., 2007) in the free ligand spectra (Table 1). After complexation, it was split into two components in the spectra of both $\mathrm{FeSO}_{4}$ and $\mathrm{FeCl}_{2}$ complexes (Fig. 4). The second component corresponds to the asymmetric stretching of the $\mathrm{Fe}-\mathrm{COO}$ bond (near $1620 \mathrm{~cm}^{-1}$ ) (Trivedi \& Vasudevan, 2007), confirming the formation of iron complexes through the interaction with the carboxyl group preferentially with the side chains of Asp or Glu residues.

At $1431 \mathrm{~cm}^{-1}$, for the complexes with both iron sources, the appearance of an important band associated with the symmetric stretching vibration of the $\mathrm{Fe}-\mathrm{COO}$ bond (Acevedo-Chávez et al., 2002) was observed. In addition, the shift in the $\nu_{s} \mathrm{C}-\mathrm{O}$ bands from 1110-1039 ( $\mathbf{H}$ and $\mathbf{F}$ ) to $1117 \mathrm{~cm}^{-1}$ in the complexes indicates the formation of $\mathrm{Fe}-\mathrm{O}-\mathrm{C}$ bonds (Chaud et al., 2002; Huang et al., 2011). However, for the complexes obtained with $\mathrm{FeSO}_{4}$, the real value cannot be observed from the IR spectra because sulfate overlaps the band in the same region (the sulfate vibrational mode is a very intense band at 1146-1150 $\mathrm{cm}^{-1}$ ) (Nakamoto, 2009). O'Loughlin et al. (2015) also observed a band at $1110 \mathrm{~cm}^{-1}$, which was assigned to a sulfate group in a fraction of whey hydrolysate added to $\mathrm{FeSO}_{4}$. Thus, much information concerning the metal-peptide interaction in $\mathrm{FeSO}_{4}$ complexes could be hidden under this broad band. The sulfate group is an integral part of the Fe complexes, either in the coordinated form, $\left[\mathrm{Fe}(\mathrm{pept}) \mathrm{SO}_{4}\right]$, or as a counter ion, $[\mathrm{Fe}$ (pept) $] \mathrm{SO}_{4}$.

Despite the differences in the MM profile of the ligands (Fig. 1), it was possible to infer metal coordination with all ligands and their ironbinding sites seem to be the same. High MM peptides (ligand $\mathbf{R}$ ) or the structure of the whole protein (WPI) did not impair the linkage with iron atoms. In fact, in a previous work (Caetano-Silva et al., 2015), we 
demonstrated that the iron-binding peptides are similar in both types of fractions (F and $\mathbf{R})$. The fragments, which are rich in the main ironbinding sites in the Asp (D) and Glu (E) residues (Chaud et al., 2002; Lv et al., 2009), were from the sequences ${ }^{42}$ YVEELKPTPEGDLEIL ${ }^{57}$ and ${ }^{124}{ }^{\text {RTPEVDDEALEK }}{ }^{135}$ from $\beta$-Lg and ${ }^{82}$ DDDLTDDI $^{89}$ from $\alpha$-La. However, it is not possible to quantify the coordinate covalent bonds formed in those different complexes. Besides the coordinate covalent bond, other interactions, such as Van der Waals forces, hydrophobic forces, and hydrogen bonding, strongly influence the peptide-Fe complex formation and even its stability (Eckert et al., 2016; Faa \& Crisponi, 1999). The differences in the complexes synthesized with different ligands may be related to the differences in in vitro iron absorption observed in a previous work (Caetano-Silva et al., 2017).

\section{(II) Influence of the iron precursor compounds}

Concerning the different iron precursor compounds, $\mathrm{FeCl}_{2}$ or $\mathrm{FeSO}_{4}$, the infrared spectroscopy also allowed identification of significant differences among the obtained complexes. The IR spectra of the free ligands (H, F, R, and WPI), as illustrated in Fig. 4, show two components of the Amide III band at $1385 \mathrm{~cm}^{-1}$ (band of medium intensity) and $1344 \mathrm{~cm}^{-1}$ (weak band) (Benaki et al., 1998) (see also Table 1). This band involves a combination of peptide $\mathrm{N}-\mathrm{H}$ in-plane bending and $\mathrm{C}-\mathrm{N}$ stretching motions, and it is conformationally sensitive (Kaiden et al., 1987). IR spectra of the complexes with $\mathrm{FeSO}_{4}$ showed the most important component of the Amide III band $\left(1385 \mathrm{~cm}^{-1}\right)$, whereas in the IR spectra of the peptide-Fe complexes formed from $\mathrm{FeCl}_{2}$, only the second component (at $1344 \mathrm{~cm}^{-1}$ ) can be observed, which can be tentatively assigned to the presence of hydrated $\alpha$-helix (Berova et al., 2012). This result is in accordance with the presence of an intense and broad $\nu \mathrm{O}-\mathrm{H}$ band at $3401 \mathrm{~cm}^{-1}$ in the spectra of $\mathrm{FeCl}_{2}$ complexes assigned to water molecule vibrations. These spectroscopic results suggest a strong local structural distortion in the $\mathrm{FeCl}_{2}$ complexes as a result of the coordination (Haris \& Chapman, 1995; Ianoul, Boyden, \& Asher, 2001).

The Amide A band, which is assigned to the stretching vibration of the $\mathrm{N}-\mathrm{H}$ bond (Barth, 2007), was observed in the spectra of the $\mathrm{FeCl}_{2}$ complexes in the same region as that of the free ligands $\left(3268 \mathrm{~cm}^{-1}\right.$, Table 1), suggesting that iron was not coordinated with the amino groups in these compounds. The $\mathrm{pH}$ of the reaction (7.0) was lower than the pKa of the $\mathrm{NH}_{3}{ }^{+}$group ( $\left.~ 9.5\right)$; thus, the majority of amino groups was protonated during the synthesis. This fact possibly hindered the formation of $\mathrm{Fe}-\mathrm{N}$ bonds. The same occurred with the complexes with $\mathrm{FeSO}_{4}$, which is in accordance with Eckert et al. (2016), who also reported that $\mathrm{Fe}^{2+}$ did not bind to the N-terminus of a heptapeptide from barley protein. However, in the $\mathrm{FeSO}_{4}$ complexes, the Amide A band exhibited a shift towards a lower wavenumber (from 3268 in free ligand to $3248 \mathrm{~cm}^{-1}$ ), suggesting an increase in hydrogen bond forces (Barth, 2007), since this band is very sensitive to the strength of hydrogen bonds (Krimm \& Bandekar, 1986). Analyzing the region associated with the $\mathrm{O}-\mathrm{H}$ stretching vibrational modes, besides the main band at $3414 \mathrm{~cm}^{-1}$, very weak bands at 3554 and $3474 \mathrm{~cm}^{-1}$, which were assigned to H-bonds (Lee et al., 2015), were observed in the spectra of the $\mathrm{FeSO}_{4}$ complexes but not in the $\mathrm{FeCl}_{2}$ complexes. Therefore, $\mathrm{FeSO}_{4}$ complexes seem to present more hydrogen bonds than the $\mathrm{FeCl}_{2}$ ones as a result of ligand-ligand interactions. This finding can be explained by the greater effect exerted by sulfate anions towards protein aggregation, which is in strong agreement with the difference in position of these ions in the Hofmeister series, as discussed earlier.

Concerning the TG and DTA curves, the complexes, $\mathbf{F}-\mathbf{F e} \mathbf{C}$ and $\mathbf{F}-\mathbf{F e} \mathbf{S}$, showed different thermal behaviors (Fig. 5), corroborating the IR results. The curve of the free ligand (F) showed the same global trend reported in the literature as the thermal behavior of the proteins (Dandurand et al., 2014; Zhang et al., 2016). The peptide-Fe complex obtained from $\mathrm{FeCl}_{2}(\mathbf{F}-\mathbf{F e} \mathbf{C})$ decomposed in three steps after the dehydration process occurred between 17 and $118{ }^{\circ} \mathrm{C}$, whereas the thermal decomposition of $\mathbf{F}-\mathbf{F e} \mathbf{S}$ occurred in only two steps after the evaporation of adsorbed water was observed in the range of $25-156^{\circ} \mathrm{C}$ (with corresponding weight loss of 6.6\%) (Fig. 5). The water loss of F-Fe C (12.4\%) was approximately $88 \%$ higher than the $\mathbf{F}-\mathbf{F e} \mathbf{S}$, which is consistent with the IR spectroscopic studies that revealed the presence of hydrated $\alpha$-helix in the complexes obtained from $\mathrm{FeCl}_{2}$ and an intense and broad $\nu \mathrm{O}-\mathrm{H}$ band at $3401 \mathrm{~cm}^{-1}$, which was assigned to water molecule vibrations (see Fig. 4).

For both complexes, step 2 (Table 2) is most likely related to the removal of coordinated water and the rupture of the peptide-iron bond, accompanied by DTA exothermic peaks at 249.1 and $265.1{ }^{\circ} \mathrm{C}$ for $\mathbf{F}-\mathbf{F e}$ $\mathbf{C}$ and $\mathbf{F}-\mathbf{F e} \mathbf{S}$, respectively. The breaking of the peptide bonds (Table 2) corresponded to the final loss of the remaining organic part, accompanied by the formation of $\mathrm{Fe}_{2} \mathrm{O}_{3}$ as the final product. For the $\mathbf{F}-\mathbf{F e} \mathbf{C}$ complex, however, one more step was observed in which the carbonaceous material slowly decomposed at a temperature from 761 to $906{ }^{\circ} \mathrm{C}$.

It is evident, therefore, that the distinct spectroscopic and thermal behaviors of $\mathbf{F}-\mathbf{F e} \mathbf{S}$ and $\mathbf{F}-\mathbf{F e} \mathbf{C}$ allowed inferring that the counter ions, which influenced the ligand-metal and ligand-ligand interactions, play a crucial role in the complex structure and its potential biological activity. Different structures can lead to different exposure of cleavage sites of gastrointestinal enzymes, which can subsequently influence the complexes digestion and iron uptake (Caetano-Silva et al., 2017; Eckert et al., 2016).

\subsection{Simplified model of peptide-iron complexes}

Fig. 6 shows a simplified model of the peptide-iron complexes, which was outlined based on our results. Other authors have also found carboxyl groups as the main iron-binding sites during the formation of peptide-iron complexes (Chaud et al., 2002; Huang et al., 2011; O'Loughlin et al., 2015; Sun et al., 2017; Zhou et al., 2012). The schematic diagram (Fig. 6) highlights the main iron linkage with the carboxyl groups via bidentate coordination and the influence of the counter ions on the ligand conformation, which results in different complexes.

\section{Conclusions}

Complexes synthesized from both iron precursor compounds, $\mathrm{FeCl}_{2}$ and $\mathrm{FeSO}_{4}$, showed metal-carboxylate coordination via the bidentate mode and different effects on the ligand conformation. The counter ions play a central role in the process of complex formation, since they may interfere either in the exposure of binding sites of the peptides or in the complex conformations. In fact, chloride or sulfate substantially affects the dynamic of peptide-Fe interaction, yielding entirely different compounds.

The adequate choice for the iron source to synthesize peptide-iron complexes may be of great importance since ligand conformation and complexes structure can lead to differences in iron absorption. Future studies may evaluate the influence of different iron precursors on the iron pro-oxidant capacity and its interaction with other compounds.

Supplementary data to this article can be found online at http://dx. doi.org/10.1016/j.foodres.2017.08.056.

\section{Acknowledgments}

The authors thank the Brazilian Biosciences National Laboratories (LNBio) for providing assistance with the fluorescence analysis and the Laboratory of Organometallic Compounds (Institute of Chemistry, UNESP) for providing assistance with the infrared and thermal analyses. This work was supported by the Fundação de Amparo à Pesquisa do Estado de São Paulo (FAPESP) [grant number 2013/10356-7]. 


\section{References}

Acevedo-Chávez, R., Costas, M. E., Bernès, S., Medina, G., \& Gasque, L. (2002). A ferrimagnetic cyclic tetranuclear copper (II) complex: Cyclo-[tetrakis $(\mu-\eta 3$-hydro-

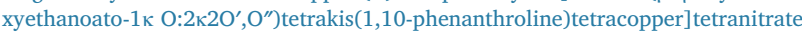
dihydrate. Structural and magnetic properties. Journal of the Chemical Society, Dalton Transactions, 12, 2553-2558.

Adams, P. D., Chen, Y., Ma, K., Zagorski, M. G., Sönnichsen, F. D., McLaughlin, M. L., \& Barkley, M. D. (2002). Intramolecular quenching of tryptophan fluorescence by the peptide bond in cyclic hexapeptides. Journal of the American Chemical Society, 124(31), 9278-9286.

Adler-Nissen, J. (1986). Enzymic hydrolysis of food proteins. New York: Elsevier Applied Science Publishers.

Arakawa, T., \& Timasheff, S. N. (1984). Mechanism of protein salting in and salting out by divalent cation salts: Balance between hydration and salt binding. Biochemistry, 23(25), 5912-5923.

Barth, A. (2007). Infrared spectroscopy of proteins. Biochimica et Biophysica ActaBioenergetics, 1767(9), 1073-1101.

Benaki, D. C., Aggeli, A., Chryssikos, G. D., Yiannopoulos, Y. D., Kamitsos, E. I., Brumley, E., ... Hamodrakas, S. J. (1998). Laser-raman and FT-IR spectroscopic studies of peptide-analogues of silkmoth chorion protein segments. International Journal of Biological Macromolecules, 23(1), 49-59.

Berova, N., Polavarapu, P. L., Nakanishi, K., \& Woody, R. W. (2012). In J. W. Sons (Vol. Ed.), Comprehensive chiroptical spectroscopy, applications in stereochemical analysis of synthetic compounds, natural products, and biomolecules. Vol. 2.

Boen, T. R., Soeiro, B. T., Pereira-Filho, E. R., \& Lima-Pallone, J. A. (2008). Folic acid and iron evaluation in Brazilian enriched corn and wheat flours. Journal of the Brazilian Chemical Society, 19, 53-59.

Caetano-Silva, M. E., Bertoldo-Pacheco, M. T., Paes-Leme, A. F., \& Netto, F. M. (2015). Iron-binding peptides from whey protein hydrolysates: Evaluation, isolation and sequencing by LC-MS/MS. Food Research International, 71, 132-139.

Caetano-Silva, M. E., Cilla, A., Bertoldo-Pacheco, M. T., Netto, F. M., \& Alegría, A. (2017). Evaluation of in vitro iron bioavailability in free form and as whey peptide-iron complexes. Journal of Food Composition and Analysis. http://dx.doi.org/10.1016/j. jfca.2017.03.010.

Callis, P. R. (2014). Binding phenomena and fluorescence quenching. Ii: Photophysics of aromatic residues and dependence of fluorescence spectra on protein conformation. Journal of Molecular Structure, 1077, 22-29.

Chaud, M. V., Izumi, C., Nahaal, Z., Shuhama, T., Bianchi Mde, L., \& de Freitas, O. (2002). Iron derivatives from casein hydrolysates as a potential source in the treatment of iron deficiency. Journal of Agricultural and Food Chemistry, 50(4), 871-877.

Dandurand, J., Samouillan, V., Lacoste-Ferre, M. H., Lacabanne, C., Bochicchio, B., \& Pepe, A. (2014). Conformational and thermal characterization of a synthetic peptidic fragment inspired from human tropoelastin: Signature of the amyloid fibers. Pathologie Biologie (Paris), 62(2), 100-107.

Dominy, B. N., Perl, D., Schmid, F. X., \& Brooks, C. L. (2002). The effects of ionic strength on protein stability: The cold shock protein family. Journal of Molecular Biology, 319(2), 541-554.

Eckert, E., Lu, L., Unsworth, L. D., Chen, L., Xie, J., \& Xu, R. (2016). Biophysical and in vitro absorption studies of iron chelating peptide from barley proteins. Journal of Functional Foods, 25, 291-301.

Faa, G., \& Crisponi, G. (1999). Iron chelating agents in clinical practice. Coordination Chemistry Reviews, 184(1), 291-310.

Gligic, L., Palic, T., \& Nikolovski, J. (2004). The beneficial effects of iron-enriched yeast Saccharomyces cerevisiae biomass in poultry breeding. Folia Veterinaria, 48(2), 104-107.

Guo, L., Hou, H., Li, B., Zhang, Z., Wang, S., \& Zhao, X. (2013). Preparation, isolation and identification of iron-chelating peptides derived from Alaska pollock skin. Process Biochemistry, 48(5-6), 988-993.

Haas, K. L., \& Franz, K. J. (2009). Application of metal coordination chemistry to explore and manipulate cell biology. Chemical Reviews, 109(10), 4921-4960.

Haris, P. I., \& Chapman, D. (1995). The conformational analysis of peptides using Fourier transform IR spectroscopy. Biopolymers, 37(4), 251-263.

Huang, G., Ren, Z., \& Jiang, J. (2011). Separation of iron-binding peptides from shrimp processing by-products hydrolysates. Food and Bioprocess Technology, 4(8), 1527-1532.

Ianoul, A., Boyden, M. N., \& Asher, S. A. (2001). Dependence of the peptide amide III vibration on the $\varphi$ dihedral angle. Journal of the American Chemical Society, 123(30), 7433-7434.

Kaiden, K., Matsui, T., \& Tanaka, S. (1987). A study of the amide III band by FT-IR spectrometry of the secondary structure of albumin, myoglobin, and $\gamma$-globulin. Applied Spectroscopy, 41(2), 180-184.

Kim, S. B., Seo, I. S., Khan, M. A., Ki, K. S., Nam, M. S., \& Kim, H. S. (2007). Separation of iron-binding protein from whey through enzymatic hydrolysis. International Dairy Journal, 17(6), 625-631.

Krimm, S., \& Bandekar, J. (1986). Vibrational spectroscopy and conformation of peptides, polypeptides, and proteins. In C. B. Anfinsen, J. T. Edsall, \& F. M. Richards (Vol. Eds.), Advances in protein chemistry. Vol. 38. Advances in protein chemistry (pp. 181364). Academic Press.

Krohn, R. I. (2001). The colorimetric detection and quantitation of total protein. Current protocols in cell biology. John Wiley \& Sons, Inc.

Lakowicz, J. R. (2006). Principles of fluorescence spectroscopy. New York: Springer.

Lee, C. M., Kubicki, J. D., Fan, B., Zhong, L., Jarvis, M. C., \& Kim, S. H. (2015). Hydrogenbonding network and $\mathrm{OH}$ stretch vibration of cellulose: Comparison of computational modeling with polarized iIR and SFG spectra. The Journal of Physical Chemistry B, 119(49), 15138-15149.

Lieu, P. T., Heiskala, M., Peterson, P. A., \& Yang, Y. (2001). The roles of iron in health and disease. Molecular Aspects of Medicine, 22(1-2), 1-87.

Luo, Y., \& Xie, W. (2012). Effect of phytase treatment on iron bioavailability in faba bean (Vicia faba 1.) flour. Food Chemistry, 134(3), 1251-1255.

Lv, Y., Guo, S., Tako, E., \& Glahn, R. P. (2014). Hydrolysis of soybean protein improves iron bioavailability by Caco-2 cell. Journal of Food and Nutrition Research, 2(4), $162-166$.

Lv, Y., Liu, Q., Bao, X., Tang, W., Yang, B., \& Guo, S. (2009). Identification and characteristics of iron-chelating peptides from soybean protein hydrolysates using IMAC$\mathrm{Fe}^{3+}$. Journal of Agricultural and Food Chemistry, 57(11), 4593-4597.

Mach, H., \& Middaugh, C. R. (1994). Simultaneous monitoring of the environment of tryptophan, tyrosine, and phenylalanine residues in proteins by near-ultraviolet second-derivative spectroscopy. Analytical Biochemistry, 222(2), 323-331.

Miquel, E., \& Farré, R. (2007). Effects and future trends of casein phosphopeptides on zinc bioavailability. Trends in Food Science \& Technology, 18(3), 139-143.

Mukherjee, S., Chowdhury, P., \& Gai, F. (2007). Infrared study of the effect of hydration on the amide I band and aggregation properties of helical peptides. The Journal of Physical Chemistry B, 111(17), 4596-4602.

Nakamoto, K. (2009). Infrared and Raman spectra of inorganic and coordination compounds part a: Theory and applications in inorganic chemistry (6 ed.). New Jersey: John Wiley and Sons.

O'Loughlin, I. B., Kelly, P. M., Murray, B. A., FitzGerald, R. J., \& Brodkorb, A. (2015). Molecular characterization of whey protein hydrolysate fractions with ferrous chelating and enhanced iron solubility capabilities. Journal of Agricultural and Food Chemistry, 63(10), 2708-2714.

Porath, J. (1990). Amino acid side chain interaction with chelate-liganded crosslinked dextran, agarose and TSK gel. A mini review of recent work. Journal of Molecular Recognition, 3(3), 123-127.

Prigogine, I., \& Rice, S. A. (2009). In J. W. Sons (Vol. Ed.), Advances in chemical physics. Vol. 111.

Schagger, H. (2006). Tricine-SDS-PAGE. Nature Protocols, 1(1), 16-22.

Sugiarto, M., Ye, A., \& Singh, H. (2009). Characterisation of binding of iron to sodium caseinate and whey protein isolate. Food Chemistry, 114(3), 1007-1013.

Sun, N., Cui, P., Jin, Z., Wu, H., Wang, Y., \& Lin, S. (2017). Contributions of molecular size, charge distribution, and specific amino acids to the iron-binding capacity of sea cucumber (Stichopus japonicus) ovum hydrolysates. Food Chemistry, 230, 627-636.

Trivedi, P., \& Vasudevan, D. (2007). Spectroscopic investigation of ciprofloxacin speciation at the goethite-water interface. Environmental Science \& Technology, 41(9), 3153-3158.

Ueno, H. M., Urazono, H., \& Kobayashi, T. (2014). Serum albumin forms a lactoferrin-like soluble iron-binding complex in presence of hydrogen carbonate ions. Food Chemistry, 145(0), 90-94.

Wu, H., Liu, Z., Zhao, Y., \& Zeng, M. (2012). Enzymatic preparation and characterization of iron-chelating peptides from anchovy (Engraulis japonicus) muscle protein. Food Research International, 48(2), 435-441.

Zhang, H., Frey, M., Navizaga, C., Lenzo, C., Taborda, J., Taifan, W., ... Baltrusaitis, J. (2016). Dairy wastewater for production of chelated biodegradable Zn micronutrient fertilizers. ACS Sustainable Chemistry \& Engineering, 4(3), 1722-1727.

Zhang, Y., \& Cremer, P. S. (2006). Interactions between macromolecules and ions: The Hofmeister series. Current Opinion in Chemical Biology, 10(6), 658-663.

Zhou, J., Wang, X., Ai, T., Cheng, X., Guo, H. Y., Teng, G. X., \& Mao, X. Y. (2012). Preparation and characterization of $\beta$-lactoglobulin hydrolysate-iron complexes. Journal of Dairy Science, 95(8), 4230-4236. 